\title{
An Indispensable Partner? \\ Bush, Obama, and the US' Soft Power
}

\section{Muhammad Shoaib*}

\author{
Dr Saira Aquil ${ }^{* *}$
}

Ahmad Sabat ${ }^{* * *}$

\begin{abstract}
Barack Obama's victory in 2008 signalled the renewal and reinforcement of soft power in the United States' foreign policy. He repudiated Bush's militaristic, messianic and unilateral approach, and strove to reduce his country's obsession with military metaphysics. He emphasised engagement, multilateralism, and restrained and proportional use of force. His moderate and pragmatist approach paid off and, except for some occasions, his administration succeeded in solving foreign policy concerns without resorting to the use of force. Thus, unlike the Bush administration, the Obama administration (with a few exceptions) showed respect for international law; and focused on the growing importance of multilateral institutions and organisations in a world shaped by the forces of globalisation and economic interdependence.
\end{abstract}

Keywords: Soft Power, Moral Credibility, Economic Interdependence, Foreign Policy, Post-Cold War Era.

The author teaches at COMSATS University, Vehari Campus, Pakistan. He is also a Visiting Researcher at the Fletcher School of Law and Diplomacy, Tufts University,

USA. He can be contacted at: shoaibm37@yahoo.com.

** The author is Assistant Professor at the Department of Defense and Strategic Studies, Quaid-i-Azam University, Islamabad, Pakistan. She can be contacted at: saquil@qau.edu.pk.

*** The author is Lecturer at COMSATS University, Vehari Campus, Pakistan. He is also a Visiting Fellow at the Department of Political Science, Columbia University, USA. He can be contacted at: ahmadsabat@ ciitvehari.edu.pk.

@2018 by the Islamabad Policy Research Institute.

IPRI Journal $\backsim \mathrm{XVIII}(2)$ : 1-25.

https://doi.org/10.31945/iprij.180201.

IPRI JOURNAL — Summer 2018 
Making sure we match our power with diplomacy, and use force wisely. Building coalitions to meet new challenges and opportunities. Leading - always - with the example of our values. That's what makes us exceptional.

- Barack Obama, State of the Union Address, 2015.

\section{Introduction}

$\mathrm{B}$ arack Obama's victory in the 2008 United States (US) Presidential Elections implied that 'change we can believe in' would not be limited to domestic politics. His victory rather signalled the renewal, and probably reinforcement, of soft power-led foreign policy. Promising to revive the US' position in the world, he rejected the crusading tone of President George W. Bush and vowed to portray the country as a state that would 'lead by example.' He viewed the US as a country with limitations of reach and power and understood its position, with some exceptions, in a multilateral context where other state actors also wielded influence. For him, soft power was an essential component of the US external policy.

One of the most difficult tasks for the Obama administration was to develop congruence between the realities of the world and the President's soft power rhetoric. For this purpose, it strove to address the challenge through a 'smart power' approach by focusing on economic revitalisation at home, and US' involvement in various multilateral institutions such as the East Asia Summit (EAS). It remained reluctant to initiate any new conflict unilaterally and, thus, tried not to do what the Bush administration had done in the past. This 'un-Bush' approach frequently brought criticism. Commentators from the US and outside considered the administration's 'Don't do stupid stuff' synonymous with inaction. ${ }^{1}$ Yet after the end of his presidency and the rise of fear mongering in the US, Obama's cautious, moderate, and pragmatist foreign policy approach

\footnotetext{
1 David Rothkopf, “Obama's 'Don't Do Stupid Shit' Foreign Policy," Foreign Policy, June 4, 2014, http://foreignpolicy.com/2014/06/04/obamas-dont-do-stupid-shit-foreignpolicy/. Rothkopf uses the term 'un-Bush' by which he means not pursuing those policies that President Bush had pursued.
} 
appeared balanced and, largely, successful. ${ }^{2}$ From accommodation and engagement with emerging global actors and promotion of free trade, his administration strove to put the US at the centre of future global strategic and economic affairs without asserting hegemonic influence unnecessarily. It succeeded in showing the world that the US would welcome the peaceful resolution of disputes and opening toward others, such as Cuba. By early 2017, his global approval ratings were generally high, and people from different parts of the world showed a high level of confidence in his leadership.

This article compares and analyses Bush and Obama's foreign policies from 2001-17, with focus on the concept of 'soft power', an important feature of post-World War II US' grand strategy. For this purpose, the concept of soft power as a comparative device is pivotal in analysing the War on Terror (WoT) years. The article argues that the Obama administration, unlike the Bush administration, showed commitment to employ soft power in foreign policy even if its (pragmatist) approach at times contradicted the soft power rhetoric - or that it continued some of Bush administration's policies.

Divided into three sections, the first covers the conceptual framework, and describes the idea of soft power (in the US context), and how it has been understood in the post-Cold War context. Section two focuses on the conservative agenda of the Bush administration, including its disdain for soft power, particularly during the first term. It highlights the policies that negatively affected the US' position (and acceptance) and antagonised friends and foes. The last section explains Obama's 'change rhetoric', describes his doctrine - placing it in both US foreign policy traditions and International Relations (IR) theories - and provides empirical evidence.

\footnotetext{
2 "Fareed: Trump's Travel Ban Fear Mongering," CNN, http://edition.cnn.com/videos/tv/2017/01/29/exp-gps-0129-take-travel-ban.cnn. Zakaria has spoken about President Trump's immigration ban and the rise of fear mongering in the US.
} 


\section{Soft Power: History, Idea and Practice}

The end of the Cold War diminished the relevance of realism as the most prominent and, probably most accepted, theory in explaining global affairs and predicting the future. Several new ideas emerged in the era of the socalled 'new world order' when prominent IR and Political Science scholars strove to fashion postulates, which were, arguably, less parsimonious and more contextual. A Harvard-based political scientist Joseph S. Nye came up with a similar idea when he wrote that success, in the Information Age, not only depended on the victory of forces, but also the story. ${ }^{3}$

The soft power concept was also a response to the scholarship pointing to the decline of the US' hard power in the international system. The 'declinists' underlined that the country's 'overstretching' had been a costly affair for the national economy, resulting in weakening of its power in the international system. ${ }^{4}$ Nye suggested that the 'declinist' assumptions were based on the "hard power" factors and excluded 'intangible resources' like ideologies, international institutions, and culture. ${ }^{5}$ He highlighted the importance of US' 'co-optive power' in its external policy through its liberal ideals, institutions, and cultures. ${ }^{6} \mathrm{He}$ saw soft power working as an 'image corrector' amongst the opposition populace across the world.

Fareed Zakaria considered the US' hegemonic power acceptability ensconced in its soft power and liberal content. ${ }^{7}$ For Nye, on the other

3 Joseph S. Nye, Jr., “Global Power Shift,” TED Talk, July 2010, http://www.ted.com/talks/joseph_nye_on_global_power_shifts/transcript?language=en.

${ }^{4}$ Paul Kennedy, The Rise and Fall of the Great Powers: Economic Change and Military Conflict from 1500 to 2000 (New York: Random House, 1987); David P. Calleo, Beyond American Hegemony: The Future of the Western Alliance (New York: Basic Books, 1987); and Samuel P. Huntington, "The US-Decline or Renewal?" Foreign Affairs 67, no. 2 (1988): 76-96, https://doi.org/10.2307/20043774.

5 Joseph S. Nye, Jr., Bound to Lead: The Changing Nature of American Power (New York: Basic Books, 1990), 31-35.

6 Ibid., 267; Joseph S. Nye Jr., The Paradox of American Power: Why the World's Only Superpower Can't Go it Alone (New York: Oxford University Press, 2002), 176.

${ }^{7}$ Fareed Zakaria, The Post-American World, 1st ed. (New York: W.W. Norton \& Company, 2008), 219, https://azadegan.info/files/Post\%20American\%20World.pdf. Zakaria posited that the US needed to give up unilateralism for multilateral diplomacy to 'remain the pivotal player in a richer, more dynamic, more exciting world.' 
hand, soft power was an essential tool to maintain US' superior status in the international system. He argued that the world was in transformation in the post-Cold War years, and that the importance of economic growth, technological advancement, and education had increased. Their importance, in effect, grew at the expense of military power. He identified five trends of this post-war age: spread of technology; growing nationalism in developing states; economic interdependence; changing political issues; and the rise of transnational actors. ${ }^{8}$ These five trends emphasised the need for ending an overwhelming reliance on hard power. His idea implied the need for leading by example so that other countries could follow the US. ${ }^{9} \mathrm{He}$ continued explaining these trends and their importance in his later works including The Paradox of American Power and The Future of Power. He had probably developed this idea on the assumption that the US power was benign and its culture, and values had sheer appeal across the globe. However, he explained that soft power was not an entirely new phenomenon, ${ }^{10}$ because the US had employed it during the Cold War by creating liberal institutions, public diplomacy, and promoting exchanges. ${ }^{11}$

According to Nye, the universal values, mentioned by President Woodrow Wilson in his famous 14 points, were perhaps the core of US' soft power. ${ }^{12}$ These values had indirectly increased the US influence across the globe because they attracted other nations. ${ }^{13}$ Nye argued that

8 Joseph S. Nye, Jr., "Soft Power," Foreign Policy, no. 80 (1990): 153-171, https://www.wilsoncenter.org/sites/default/files/joseph_nye_soft_power_journal.pdf.

9 Joseph S. Nye, Jr., "The Benefits of Soft Power" (Boston: Harvard Business School Working Knowledge, 2004), http://hbswk.hbs.edu/archive/4290.html.

${ }^{10}$ Nye has identified three different ways to affect another's behaviour: coercion with threats; inducement of incentives; and exercising the power of attraction to make them do the same thing you are doing. He terms the latter as 'soft power.'

${ }^{11}$ Joseph S. Nye, Jr., The Paradox of American Power: Why the World's Only Super Power Can't Go it Alone, 72.

${ }^{12}$ Joseph S. Nye, Jr., The Future of Power (New York: Public Affairs, 2011). Nye identified three broad sources: culture, political values, and policy. Enterprise, digital infrastructure, and education may also increase attraction.

${ }^{13}$ G. John Ikenberry, "Institutions, Strategic Restraint, and the Persistence of American Postwar Order," International Security 23, no. 3 (1998/9): 43-78, https://doi.org/10.1162/isec.23.3.43. Ikenberry portrayed the US hegemony as 'reluctant, open, and highly institutionalized - or, in a word, liberal.' Sandy Berger maintained that the US had defined and pursued its interests in congruence with the 'common good rising prosperity, expanding freedom, and collective security.' 
hard power had enormous use in the US' Cold War policy. But the forces of the post-war age, such as economic interdependence and globalisation would reduce the utility of hard power. Similarly, the worldwide use of the Internet, and subsequent flow of information through it, contrary to print and electronic media, would reduce governmental authority over information. Globalisation, in effect, could provide the US with an opportunity to lead by example. In 1992, however, Barber argued that the US' values were 'not welcome[d] everywhere in the world,' and that their advancement reinforced by technological development, a strong economy, and communication, would fuel resentment in different regions, particularly the Middle East, due to its domineering reach. ${ }^{14}$ Even so, Nye's idea of soft power was a welcome narrative in the realismdominated foreign policy discourse. Yet his critics such as Krauthammer paralleled his idea with a popularity contest, and became an ardent advocate of 'New Unilateralism' during the first term of the Bush administration.

As for the US' soft power, in some cases, the overwhelming reliance on hard power overshadowed the soft power of the Cold War. For instance, the long-held expectations of peace at the end of the war proved mere expectations on the eve of the Gulf War in 1991. The country's allies, and potential competitors alike, witnessed the demonstration of its military superiority. The crises, and resulting use of force in the Middle East and the Caribbean led to the deployment of troops in several countries. In fact, the US launched 48 military operations in a decade (1989-99) as compared to 16 during the Cold War. ${ }^{15}$ Mills termed this obsession with military power as 'military metaphysics. ${ }^{, 16}$

Similarly, during the early Twenty-first Century, the US' leadership showed little appetite for projection of soft power, especially while starting the global campaign against terrorism. In effect, despite

${ }^{14}$ Benjamin R. Barber, "Jihad vs. McWorld,” Atlantic, March 1, 1992, http://www.theatlantic.com/magazine/archive/1992/03/jihad-vs-mcworld/303882/.

${ }^{15}$ Morris Berman, Dark Ages America: The Final Phase of Empire (New York: W.W. Norton \& Company, 2006), 145.

${ }^{16}$ C. Wright Mills, The Power Elite (New York: Oxford University Press, 2000), 202-206. 'Military metaphysics' means a parochial way of viewing international problems through military power. 
emphasising the use of soft power and embracing multilateralism, the Clinton administration (1993-2001) folded the US Information Agency (USIA) into the State Department in the mid-1990s. Such fora had not only disseminated the US' ideals and values in Europe and Asia, but they had also attracted those living on the other side of the Iron Curtain. ${ }^{17}$ Although Clinton made efforts to emphasise the US' soft power, his policies were often contradictory. His military interventions, and an overwhelming use of hard power tools, espoused the notion that any type of retreat from 'military metaphysics' would be difficult.

\section{The Bush Administration and US' Exceptionalism}

The Bush administration entered the White House with higher aims. It emphasised 'national interest' and pledged to build strategic trust with other great powers. ${ }^{18}$ However, it appeared to have rejected the idea of putting soft power on its priority list. In effect, before their victory in the 2000 elections, some of the neoconservatives (neocons) had already been building their case for the elevation of hard power in the US' foreign policy. For instance, then-Secretary of State, Condoleezza Rice stated that the world had room for only one hegemon. ${ }^{19}$ Neoconservatives emphasised that the Clinton administration's humanitarian interventions had proved detrimental to the US' strategic interests.

Nonetheless, they could not move ahead with the proposed policies. One of the most important obstacles was 9/11, and the subsequent global campaign against terrorism. Still, this campaign provided certain stakeholders in the administration with an opportunity to emphasise the US' military power. Relations with other great powers were generally cooperative. However, the campaign in the Middle East and South Asia reflected the arrogance of US power. In this backdrop, the Iraq War essentially proved detrimental to the US' image across the world.

\footnotetext{
${ }^{17}$ Joseph S. Nye, Jr., "The Decline of America's Soft Power," Foreign Affairs, May/June 2004, http://www.foreignaffairs.com/articles/59888/joseph-s-nye-jr/the-decline-ofamericas-soft-power.

${ }^{18}$ Condoleezza Rice, "Campaign 2000: Promoting the National Interest," Foreign Affairs, January/February 2000, https://www.foreignaffairs.com/articles/2000-01-01/campaign2000-promoting-national-interest.

19 Berman, Dark Ages America: The Final Phase of Empire, 150.
} 
Conversely, Lynch and Singh argued that 9/11 did not completely change the US' foreign policy because unilateralism and promotion of democracy were already part of the 2002 National Security Strategy (NSS). ${ }^{20}$

Bacevich has viewed this debate in a different perspective. He argued that the WoT amplified the existing militaristic tradition and negatively affected the Americans' ability to think. ${ }^{21}$ The administration's emphasis on relying on military superiority, and a contemptuous attitude towards international institutions and allies, presented a clear indication of deviation from the liberal internationalist tradition. Smith referred to Bush's policies as his 'commitment to liberal international imperialism.' 22 According to Nossel:

After the 9/11 incident, the conservatives adopted the symbols of liberal internationalism in their aggressive unilateralist strategy, although both were incompatible and inconsistent. ${ }^{23}$

9/11 provided the Bush administration with a framework to manifest the neoconservative interpretation of US power. The desire to maintain US' supremacy and commitment to 'a new way of war' showed the least propensity to soft power. ${ }^{24}$ The belief that 'democracy can be promoted' through the US' military imperiousness; disregard for allies and international institutions; and indifference to international law and norms brought decisive changes in the targeted countries. Bush's commitment to exceptionalism probably induced in him 'disregard for

${ }^{20}$ Timothy J. Lynch and Robert S. Singh, After Bush: The Case for Continuity in American Foreign Policy (New York: Cambridge University Press, 2008). Also see, White House, GoUS, The National Security Strategy of the United States of America" (Government of United States, 2002), https://www.state.gov/documents/organization/63562.pdf.

${ }^{21}$ Andrew J. Bacevich, The New American Militarism: How Americans Are Seduced by War (Oxford: Oxford University Press, 2005), 9-33.

${ }^{22}$ Tony Smith, A Pact with the Devil: Washington's Bid for World Supremacy and the Betrayal of the American Promise (New York: Routledge, 2007), xxxvi.

${ }^{23}$ Suzanne Nossel, "Smart Power," Foreign Affairs, March/April 2004, https://www.foreignaffairs.com/articles/united-states/2004-03-01/smart-power.

${ }^{24}$ Joseph S. Nye, Jr., "Think Again: Soft Power," Foreign Policy, February 23, 2006, https://foreignpolicy.com/2006/02/23/think-again-soft-power/. 
international law to preserve US freedom of action. ${ }^{, 25}$ Hoffmann argues that the Bush administration's understanding of exceptionalism was 'troubling.' He argued that the claim justifying disregard for international law and organisations was 'bizarre':

The most bizarre may be the claim that the US Constitution allows no bowing to a superior law... and no transfer, pooling, or delegation of sovereignty to any international organisation. ${ }^{26}$

The Department of Defense (DoD) officials' arrogance, despite the North Atlantic Treaty Organization (NATO)'s invocation of Article V immediately after 9/11, disillusioned allies and, later, made it harder for the US to secure their commitment to counterinsurgency and reconstruction in the targeted countries. ${ }^{27}$

The neoconservatives' apathy towards international law and organisations also influenced the administration's United Nations (UN) policy. Considering the international treaties and regimes as a limitation on the US' power, they showed little interest in aligning with others at multilateral fora. ${ }^{28} \mathrm{~A}$ few, among the administration such as thenSecretary of State Colin Powell (served under Bush 2001-05), emphasised soft power, respect for international law and organisations, and applicability of the Geneva Conventions. He conveyed his concerns about disregarding the Conventions in early 2002. Their suspension, according to Powell, could reduce public support and invited (undesirable) international reaction. ${ }^{29} \mathrm{He}$ was outnumbered, however, by the

\footnotetext{
${ }^{25}$ Stanley Hoffmann, "The High and the Mighty," The American Prospect, December 19, 2002, http://www.prospect.org/article/high-and-mighty. Hoffmann terms it 'new exceptionalism' while Bush called it 'distinctly American internationalism.'

${ }^{27}$ Ahmed Rashid, Descent into Chaos: The United States and the Failure of Nation Building in Pakistan, Afghanistan, and Central Asia, 1st ed. (New York: Penguin Group, 2008), 61-84.

${ }^{28}$ Elliot Abrams, “American Power - For What?" Commentary, January 1, 2000,

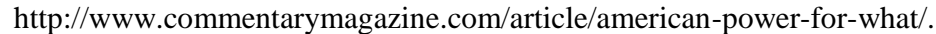

${ }^{29}$ Ellen Hallams, "From Crusader to Exemplar: Bush, Obama and the Reinvigoration of America's Soft Power," European Journal of American Studies 6, no. 1 (2011), doi: 10.4000/ejas.9157.
} 
neoconservatives, who did not want their engagement restrained by laws and norms. ${ }^{30}$

During the first term of the Bush administration (2001-04), the War Council's arguments secured sufficient popularity in the US and abroad. For instance, in 2002, Robert Kagan wrote, the 'US seeks freedom of action to deal with the strategic dangers.' He referred to Robert Cooper who coined the idea of a 'post-modern state' with respect to the nationstates. $^{31}$ In one of his essays, muscular multilateralist Cooper supported the idea of adopting double standards, especially while dealing outside Europe and the US. He explained:

Among ourselves, we keep the law, but when we are operating in the jungle, we must also use the laws of the jungle. ${ }^{32}$

The Bush administration, in general, adopted a similar pattern of thinking. Officials justified that because the US was fighting against an unusual enemy (transnational terrorists, Jihadists) operating according to the 'laws of the jungle', it reserved the right to exceed international institutions and laws and use the 'laws of the jungle.' The administration terminated the Anti-Ballistic Missile Treaty (1972-2002); denounced the Kyoto Protocol to the UN Framework Convention on Climate Change; rejected the idea of nation-building; and based agreements on a rather parochial definition of national interest. ${ }^{33}$

On the administration's unilateralism, Francis Fukuyama argued that it had failed to understand the adverse reaction to its policies. He criticised it for neglecting the value of securing legitimacy, which soft power underpinned. ${ }^{34}$ In fact, Bush's foreign policy was described as:

\footnotetext{
${ }^{30}$ Ibid.

${ }^{31}$ Robert Kagan, Of Paradise and Power: America and Europe in the New World Order (New York: Alfred A. Knopf, 2003), 76, http://commonweb.unifr.ch/artsdean/pub/gestens/f/as/files/4760/33518_121406.pdf.

${ }^{32}$ Robert Cooper, “The Post-Modern State and the World Order" (essay, Demos, London, 2000), www.demos.co.uk/files/postmodernstate.pdf.

${ }^{33}$ Nossel, "Smart Power."

${ }^{34}$ Francis Fukuyama, "The Neoconservative Moment," The National Interest, June 1, 2004, http://nationalinterest.org/article/the-neoconservative-moment- 811 .
} 


$$
\begin{aligned}
& \text { Unipolarity }+9 / 11+\text { Afghanistan }= \\
& \text { Unilateralism }+ \text { Iraq. }
\end{aligned}
$$

The Bush doctrine consisted of four broad tenets:

1. Belief in the importance of state's domestic regime in determining its external policy.

2. Threats can only be defeated by a new approach, such as preventive war.

3. Willingness to act alone - unilateralism.

4. The US' primacy for world peace and stability. ${ }^{36}$

The failure of the first term, exposed by the campaign in Iraq, constrained the (second term) Bush administration to consider soft power in the execution of foreign policy. The second term (2005-09), therefore, witnessed several changes. The administration emphasised public diplomacy and established Radio Sawa (2004) to attract the Arabs, particularly in the Middle East. ${ }^{37}$ President Bush also admitted his first term failures, and accepted that 'his administration failed to sell the US story. ${ }^{38}$ To 'sell the story', it needed to employ soft power, which, in the early years, it did not. Then-Secretary of Defense Robert Gates (who served under both Bush [2006-09] and Obama [2009-11]) also objected to the lack of resources devoted to public diplomacy. ${ }^{39}$ Against this backdrop, the administration belatedly started several public diplomacy

\footnotetext{
${ }^{35}$ Zakaria, The Post-American World, 223.

${ }^{36}$ Robert Jervis, "Understanding the Bush Doctrine," Political Science Quarterly 118, no. 3 (2003): 365-388, doi: 10.1002/j.1538-165X.2003.tb00398.x; — , "Why the Bush Doctrine Cannot be Sustained," Political Science Quarterly 120, no. 3 (2005): 351-377, https://doi.org/10.1002/j.1538-165X.2005.tb00550.x.

${ }^{37}$ Hallams, "From Crusader to Exemplar."

${ }^{38}$ Ibid.

${ }^{39}$ William Matthews, "Can Obama Get Results From 'Soft Power'?” Small Wars Journal Blog, January 19, 2009, http://smallwarsjournal.com/blog/can-obama-get-results-fromsoft-power.
} 
initiatives such as Public Diplomacy 2.0, but these efforts had limited effect because most of them were a one-way channel of information. ${ }^{40}$

\section{Obama and Reinvigoration of the US' Soft Power}

The Obama doctrine was based on two ideas of accommodation and retrenchment. ${ }^{41}$ However, he did not strictly follow any IR theory or foreign policy traditions. His doctrine, instead, fell within defensive realism and multilateralism. Following George Kennan's feats, Obama showed, unlike Bush, minimum interest in promoting the idea of US exceptionalism, and employing excesses to pursue his goals. ${ }^{42}$ As a moderate and pragmatist, he highlighted the limits of US' power. He took the initiative of reaching out to 'others'; admitting the country's external policy flaws and their cost; publicising offers for engagement; putting restraints on the use of force; promoting international institutions as the solution to global political and strategic problems; and highlighting his intent to 'lead by example.'

Declaring his opposition to all 'rash and dumb wars', President Obama assured the world that his administration would listen, not just dictate outcomes. His foreign policy, in general, remained largely close to themes he based his campaign on.

${ }^{40}$ R. S. Zaharna, "Obama, US Public Diplomacy and the Islamic World," World Politics Review, March 16, 2009, https://www.american.edu/soc/faculty/upload/zaharna-publicdiplomacy-islamic-world.pdf.

${ }^{41}$ Colin Dueck, The Obama Doctrine: American Grand Strategy Today, 1st ed. (New York: Oxford University Press, 2015). Obama was more accommodationist and conciliatory than Nixon and Kissinger during détente.

42 Robert G. Kaufman, Dangerous Doctrine: How Obama's Grand Strategy Weakened America (Lexington: University Press of Kentucky, 2016), 1-23, 27-35, 39-58. The Obama doctrine did not fit completely into the Jeffersonian, Hamiltonian, Jacksonian, or Wilsonian traditions that Walter Russell Mead suggested. It rejected Krauthammer and Weigel's 'moral democratic realism'; Henry Nau's six traditions including Washington's minimalist nationalism; conservative internationalism of Polk, Truman, and Jefferson; Wilson and Franklin Delano Roosevelt Sr. (FDR)'s liberal internationalism; the latter's offensive realism; Jackson's militant nationalism; and Nixon's defensive realism. Stephen Sestanovich's commitment and underperformance cycles were also limited in explaining the Obama doctrine. The doctrine was rather balanced, mixed, and transcending. 
An Indispensable Partner? Bush, Obama, and the US' Soft Power

The primary tenets of the Obama doctrine were:

1. Protect the world and the US from arrogance of the latter's power and hubris.

2. Multilateralism over unilateralism.

3. Minimum importance to nature of regime in determining its foreign policy.

4. Proportional, multilateral, restrained, and justified use of force.

5. Soft power, diplomacy, and engagement.

6. Reduction in the US' commitments abroad. ${ }^{43}$

Obama's 'Change We Can' slogan brought hope in the US and the outside world that his administration would reduce military engagements and stay away from liberal imperialism. He portrayed himself as a symbol of change. In his campaign, he vowed to restore the US' moral credibility and withdraw the armed forces from other countries, such as Iraq. The notions of withdrawal and putting soft power on lead in foreign policy convinced the audience, both local and international, that the US' obsession with 'military metaphysics' would diminish in the future - if not end completely. ${ }^{44}$ Obama's team appointments also made his intent clear. He retained a few Bush administration officials, like John Brennan as Counterterrorism Advisor; and Gates as Secretary of Defense. The appointment of Bush-era officials led critics to question how far he was ready to deviate from his predecessor's policies. Inderjeet Parmar wrote:

${ }^{43}$ Ibid., 1-23. His reluctance for regime change in Russia, Iran and Syria was explicit. As for proportional and restrained use of force, Afghanistan, Pakistan, and Somalia topped the lists. Even after the Osama bin Laden raid, the US and Pakistani authorities, particularly the Army, continued to cooperate and coordinate regarding militants' positions. At the same time, the Obama administration encouraged China's increased involvement with Pakistan and Afghanistan.

${ }^{44}$ Bacevich, The New American Militarism: How Americans Are Seduced by War, 9-33. C. Bacevich argues that the US, in the post-World War II era, became committed to exporting the benign Wilsonian values with the help of military means and considered military power to be the true symbol of national greatness. 
If the President was serious about change, he would not have appointed them in his administration. ${ }^{45}$

Hallams, however, supported Obama's decision and argued that these appointments showed the realisation of an inexperienced President that he required an experienced team to maintain continuity in some policies, and deal with two major conflicts and growing instability. ${ }^{46}$

The first few months of his administration showed that Obama was interested in changing the foreign policy approach rather than the foreign policy team. ${ }^{47}$ His multicultural experience and sensitivity to the difference in rhetoric and actions of the US shaped his views on foreign policy, which was inevitably different from his predecessor. He embraced Nye's view that 'how others saw America did matter' and shared the idea that 'the US needed others to achieve the desired outcomes. ${ }^{48}$ In his inaugural address, he shared his own view on the link between 'American ideals and safety' as, 'We reject as false the choice between our safety and our ideals. ${ }^{49}$ Given the idea of change and a vow to restore the US' moral credibility, his four executive orders did not come as a surprise. ${ }^{50}$

Obama also sought to undo (some of) the damage done by his predecessor. In Cairo, he announced a new strategy based on mutual

\footnotetext{
${ }^{45}$ Inderjeet Parmar, "Plus Ca Change? American Foreign Policy under Obama," Political Insight 1, no. 1 (2010): 14-16, https://doi.org/10.1111/j.2041-9066.2010.00007.x.

${ }^{46}$ Hallams, "From Crusader to Exemplar." The US was not alone in wars in Afghanistan and Iraq. Sudden changes in policy and personnel could have sent a wrong message to allies and partners.

${ }^{47}$ Dueck, The Obama Doctrine: American Grand Strategy Today, 1-11. According to some accounts, Obama wanted to have a greater focus on domestic priorities.

${ }^{48}$ Nye, Jr., "Think Again: Soft Power."

${ }^{49}$ Barack Obama, "President Barack Obama's Inaugural Address" (speech, Washington, D.C., January 21, 2009), White House, https://obamawhitehouse.archives.gov/blog/2009/01/21/president-barack-obamasinaugural-address.

${ }^{50}$ Obama's Executive Orders included suspension of military tribunals at Guantanamo Bay and a pledge to close it within one year; closure of the Central Intelligence Agency (CIA)'s secret prisons; prohibition of torture; and reviewing the detention policies. At the end of his second term, Obama had clearly failed to close the Guantanamo Bay prison, but he was able to reduce its population to 41 . According to him, the most notable impediment in closing 'Gitmo' was Congress.
} 
respect and interest towards the Arab world. ${ }^{51}$ In April 2009, he participated in a global conference on nuclear security, and announced his goal of a world free of nuclear weapons - the speech that also won him the 2009 Nobel Peace Prize. He sought to revitalise US diplomacy and the trust of allies. In 2011, he stated with reference to the case of Libya (where France and Britain led the intervention):

American leadership is not simply a matter of going it alone... Real leadership creates conditions and coalitions... to work with allies and partners... and to see that the principles of justice and human dignity are upheld by all. ${ }^{52}$

\section{Rhetoric to Action: Obama's First Term (2009-13)}

The Obama administration took less time in understanding the dilemma in the country's external policy where ideals and interests often suggested contrary paths. The President ordered surge in the number of troops deployed in Afghanistan in February 2009. His Afghanistan-Pakistan (AfPak) policy, thus, led critics to question his soft power instincts. His decision to rely on drone strikes in Afghanistan, and Pakistan's tribal areas also led some to even call him Bush-lite. Lynch and Singh paralleled Obama with the Cold War Democratic hawks. ${ }^{53}$ The dilemma of balancing soft power and the realities of the world was usually clear, and Obama accepted this dilemma in his Oslo speech and strove to justify the use of force. ${ }^{54}$ Yet his conformity to the use of force did not put him in

${ }^{51}$ Barack Obama, "Remarks by the President at Cairo University" (speech, Cairo, June 4, 2009), White House, https://obamawhitehouse.archives.gov/the-press-office/remarkspresident-cairo-university-6-04-09.

52 Barack Obama, "Remarks by the President in Address to the Nation on Libya" (speech, Washington D.C., March 28, 2011), White House, https://obamawhitehouse.archives.gov/the-press-office/2011/03/28/remarks-presidentaddress-nation-libya.

${ }^{53}$ Timothy Lynch and Robert Singh, "Obama...The Liberal Reagan or Just a Black Jimmy Carter?" Yorkshire Post, July 22, 2008,

http://www.yorkshirepost.co.uk/news/opinion/timothy-lynch-and-robert-singh-obamathe-liberal-reagan-or-just-a-black-jimmy-carter-1-2509798.

${ }^{54}$ Barack Obama, "Remarks by the President at the Acceptance of the Nobel Peace Prize" (speech, Oslo, December 10, 2009), White House, 
line with his predecessor. They were different in rhetoric - even if there were a few similarities in their actions. ${ }^{55}$ Contrary to Bush, Obama accepted the supremacy of international law and organisations in several critical matters, such as military intervention. He focused on the US' alliances, particularly in Europe and the Asia-Pacific and, joined new multilateral fora such as the EAS. Similarly, his administration avoided following the Bush-version of Wilsonianism in Asia and the Middle East, because he wanted the US to be considered an indispensable partner, but at the same time avoided assuming its (global) role as an indispensable patron. $^{56}$

Bob Woodward identified Obama's belief that continued presence of the US forces in Afghanistan and Iraq would reinforce the notions of occupation amongst the populace. ${ }^{57}$ His emphasis on withdrawal made sense when understood in the context of growing anti-Americanism; and the US portrayal as an imperial power across the world. The same 'military metaphysics' had also affected relations with allies, particularly in Asia. The same allies, who despite sharing responsibilities in the WoT, probably did not identify themselves with the Bush administration in its obsession with terrorism. The Obama administration understood this problem; and, so, reviving alliances and sharing burden and responsibility became the hallmark of his first term foreign policy. ${ }^{58}$

https://obamawhitehouse.archives.gov/the-press-office/remarks-president-acceptancenobel-peace-prize.

${ }^{55}$ See, Michael J. Glennon, National Security and Double Government (New York: Oxford University Press, 2014). A completely new foreign policy in the US context was perhaps a naïve expectation. Bringing change in the organisational culture, particularly dealing with defence-related matters, needed time and effort.

${ }^{56}$ Since his early days in office, Obama was in favour of not getting involved in military operations. Unlike his predecessor, he stated that the US must lead in the spirit of a partner.

57 Bob Woodward, Obama's Wars (New York: Simon \& Schuster, 2010), 167. It was under Obama's leadership when the US military commanders emphasised looking beyond killing the enemy. Rohan Teneja, "Soft Power and Obama's Grand Strategy: A Conversation with Dr Joseph S. Nye, Jr.," Duke University Program in American Grand Strategy, March 24, 2010, https://sites.duke.edu/agsp/2016/11/27/soft-power-andobamas-grand-strategy-dr-joseph-nye-jr-former-assistant-secretary-of-state-to-presidentbill-clinton/.

${ }^{58}$ Woodward, Obama's Wars, 294. 
In early 2009, for instance, the administration made a rigorous endeavour to reach out to allies, especially NATO. Contrary to the previous US practice of forcing allies to do more, Obama increased funding for civilian reconstruction projects. ${ }^{59}$ The State Department Advisor on Europe Jeremy Shapiro commented that 'Obama intended sharp break with the past. ${ }^{, 60}$ During his trip to Munich in February 2009, Vice-President Joe Biden explained that the 'administration sought to strengthen its relationship with Europe', although he also stated that the US would expect more from its European partners in return for this new tone. ${ }^{61}$ French President Nicolas Sarközy welcomed this and expressed his confidence in the new US President. ${ }^{62}$

Nonetheless, the equilibrium between soft power instincts and balance of power was at times missing. If the Bush administration had faced criticism for its unilateralism, the Obama administration faced criticism for its inaction and indecisiveness. The US' closest ally, Israel, occasionally felt betrayed by his administration. Benjamin Netanyahu resisted the administration's demand for halting construction of settlements. ${ }^{63}$ Obama's Egypt policy, in wake of the Arab Spring, also faced severe criticism. His critics called his diplomacy naïve, smug, and

${ }^{59}$ Hallams, "From Crusader to Exemplar."

${ }^{60}$ Michael D. Shear and Scott Wilson, "On European Trip, President Tries to Set a New, Pragmatic Tone," Washington Post, April 5, 2009, http://www.washingtonpost.com/wpdyn/content/article/2009/04/04/AR2009040400700.html.

${ }^{61}$ Joe Biden, "Remarks by Vice-President Biden at $45^{\text {th }}$ Munich Conference on Security Policy" (speech, Munich, February 7, 2009), White House, https://obamawhitehouse.archives.gov/the-press-office/remarks-vice-president-biden45th-munich-conference-security-policy.

${ }^{62}$ Shear and Wilson, "On European Trip, President Tries to Set a New, Pragmatic Tone." It is noteworthy that Sarközy had advised Rice to improve the US' image, and shared his concern about the country's growing unpopularity, and consequent problems for the allies in working with the most powerful, yet the most unpopular state.

63 Jeffrey Goldberg, "The Crisis in US-Israel Relations is Officially Here," Atlantic, October 28, 2014, http://www.theatlantic.com/international/archive/2014/10/the-crisisin-us-israel-relations-is-officially-here/382031/; and David Rothkopf, "The Last Act of Obama's Israel Drama May be his Best," Foreign Policy, December 28, 2016, https://foreignpolicy.com/2016/12/28/the-last-act-of-obamas-israel-drama-may-be-hisbest-palestine-settlements-un-kerry/. The 2016 UN vote reflected Obama's instincts. This vote showed Israelis and American Jews the diminishing support for Israel's policy across the world. However, Obama and his close aides had to work hard for this consensus and put the US in the leadership position. 
heedless of risks. ${ }^{64}$ For instance, Ryan Lizza argued that the protests in Egypt had exposed the administration's contradictions, which trying to both contain and encourage the revolutionary forces. ${ }^{65}$ Obama's antipathy to rollback the US' reliance on Egypt's Hosni Mubarak, were seemingly in contradiction.

Obama's pro-engagement and multilateralist approach - for some, hands-off approach - towards Iran and Syria also became a target of criticism. His China ${ }^{66}$ and Russia ${ }^{67}$ policies, and the resulting failure in building constructive relations with them also enticed disapproval. On balance, his first term foreign policy focused on avoiding initiating new conflicts (particularly unilateralism); revitalising the US' moral credibility (soft power); reducing military engagements; and building strategic trust with other great powers.

\section{Don't Do Stupid Stuff: Obama's Second Term (2013-17)}

Obama's second term team had a few new faces, and included changes in the DoD and Department of State (DoS). John Kerry took charge as Secretary of State, while Chuck Hagel, a like-minded Republican, was appointed Secretary of Defense. The second term witnessed developments

\footnotetext{
64 "Egypt Protests," Guardian News Blog, January 31, 2011, https://www.theguardian.com/news/blog/2011/jan/31/egypt-protests-live-updates.

${ }^{65}$ Ryan Lizza, "The Consequentialist: How the Arab Spring Remade Obama's Foreign Policy," New Yorker, May 2, 2011, http://www.newyorker.com/magazine/2011/05/02/the-consequentialist.

66 "China Condemns 'Groundless' US Criticism of Web Control," BBC News, January 22 2010, http://news.bbc.co.uk/2/hi/asia-pacific/8474011.stm. In response, Chinese officials frequently criticised the US policies and accused it of informational imperialism. They also considered the 'rebalance' to Asia as an attempt to contain the rise of China.

${ }^{67}$ Michael E. O'Hanlon, "Rebalancing the US Military in Asia and the Pacific," Brookings, June 9, 2013, https://www.brookings.edu/opinions/rebalancing-the-u-smilitary-in-asia-and-the-pacific/; and Michael O'Hanlon, "Glass Half Full? Obama's Judicious Foreign Policy Record," Order from Chaos Blog, March 11, 2016, https://www.brookings.edu/blog/order-from-chaos/2016/03/11/glass-half-full-obamasjudicious-foreign-policy-record/. After assuming office, Obama announced a reset of relations with Russia. The US' diplomacy secured Russia's support for sanctions against Iran, yet it failed on the Syrian question. Both sides were also at odds after the onset of the Ukrainian conflict. The administration moved from constructive and cooperative relations to 'rebalance.'
} 
in the Middle East, Asia, and Europe. The conflicts in Syria and Ukraine put the administration in a difficult situation - working with and countering Russia, simultaneously. Wary of repeating the mistakes committed in Libya - where tribalism, incompetence of US' European allies, and misplaced expectations created a 'mess' - Obama emphasised potential diplomatic solutions for both conflicts. His administration worked with Russia in managing chemical weapons in Syria. ${ }^{68}$ Also, it showed commitment to a peaceful solution of the Iranian (nuclear) crisis. $^{69}$

In a broader sense, Obama's second term did not witness any radical shift in foreign policy. Pragmatism, case-by-case method, and smart power approach continued to be the key variables in shaping the policymaking process. The notion of smart power particularly became popular with the administration because it posited intelligent use of all available resources. It comprised of a combination of different tools, including diplomacy, economic, cultural, and military power, in which diplomacy would lead. ${ }^{70}$ Indyk, Lieberthal, and O'Hanlon argue:

Obama has been a progressive where possible but a pragmatist when necessary. And given the domestic and global situations, he has faced, pragmatism has dominated. ${ }^{71}$

The Obama administration endeavoured to deal with most problems in their context. This practice led foreign policy experts to question

\footnotetext{
${ }^{68}$ For a detailed account, see, Barack Obama, “The Obama Doctrine," interview by Jeffrey Goldberg, Atlantic, April 2016, https://www.theatlantic.com/magazine/archive/2016/04/the-obama-doctrine/471525/; and Michael R. Gordon, "US and Russia Reach Deal to Destroy Syria's Chemical Arms," New York Times, September 14, 2013, http://www.nytimes.com/2013/09/15/world/middleeast/syria-talks.html.

69 "Obama will Veto any Bill Blocking Implementation of Iran Nuclear Deal," CBS News, July 14, 2015, http://www.cbsnews.com/news/obama-will-veto-any-bill-that-preventsimplementation-of-iran-deal/.

70 “Transcript of Clinton's Confirmation Hearing," NPR, January 13, 2009, https://www.npr.org/templates/story/story.php?storyId=99290981.

${ }^{71}$ Martin Indyk, Kenneth Lieberthal, and Michael E. O'Hanlon, "Scoring Obama's Foreign Policy: A Progressive Pragmatist Tries to Bend History," Foreign Affairs, May/June 2012, http://www.foreignaffairs.com/articles/137516/martin-indyk-kennethlieberthal-and-michael-e-ohanlon/scoring-obamas-foreign-policy.
} 
whether the US had any grand strategy, or if Obama had any doctrine. Obama defended his situation-specific approach:

When you start applying blanket policies on the complexities of the current world situation, you're going to get yourself into trouble. $^{72}$

Critics, however, blamed the administration for failure to wield influence, and thus, representing a declining US. Obama's foreign policy approach and soft power instincts harmed the US' global standing and enabled rising states to expand their influence at its expense. His policy, aimed at having constructive relations with major powers especially China, affected US treaty allies in Asia, particularly Japan. Republicans objected to his approach towards Israel, Iran, Syria, and Ukraine. They considered his policies weak and indecisive; whilst the left saw them in the context of the Bush administration's foreign policy. They pointed out similarities in the policies of both administrations. ${ }^{73}$ In this backdrop, Noah Bonsey criticised the Syria policy and argued that it would take the US nowhere. He explained that the administration's inaction in Syria was not only increasing Jihadis' appeal in the region, but also 'leaving the door open for the Islamic State (IS) to expand into new areas. ${ }^{74}$

Contrary to Syria, the reactions to Obama administration's Af-Pak policy remained mixed. The administration moved forward with planned withdrawal from Afghanistan, which suggested an end to taking lead in fighting missions. The administration relied on drone strikes as a counterterrorism tool and targeted militants across the border in Pakistan's Federally Administered Tribal Areas (FATA) and Balochistan. The use of drones to track down militants brought severe criticism from human rights' groups. Yet, from the US' point-of-view, the drone-based targeting strategy was successful, particularly in Pakistan. Parallel to drone strikes,

72 “Obama's Foreign Policy: The First Two Years,” NPR, April 27, 2001,

http://www.npr.org/2011/04/27/135746117/obamas-foreign-policy-the-first-two-years.

${ }^{73}$ Tariq Ali, The Obama Syndrome: Surrender at Home, War Abroad (New York: Verso, 2010), 73.

${ }^{74}$ Noah Bonsey, "What Obama doesn't Understand about Syria," Foreign Policy, November 26, 2014,

http://foreignpolicy.com/2014/11/26/what-obama-doesnt-understand-about-syria/. 
An Indispensable Partner? Bush, Obama, and the US' Soft Power

the administration continued to work with Pakistan, China, and Afghanistan to negotiate with the Taliban.

The Afghan negotiation process went ahead parallel with the Ukraine issue and P5+1 ${ }^{75}$ talks with Iran. Obama's reluctance to initiate a conflict with Russia over Ukraine, a strategic interest for the latter, led some to disapprove of his position on the matter. For them, probably, Russia's seizure of Crimea was an anomaly of the Twenty-first Century. Yet, the US' response emboldened the Kremlin and exposed smaller NATO members to the Russian threat. Critics such as Rothkopf challenged the decision of placing sanctions on 'Putin's Russia' and termed his actions as laughable. ${ }^{76}$ Obama, however, was clear on his stance. He defended his multilateralist approach and pointed to the unity of allies in the wake of the Russian threat. ${ }^{77}$

Similarly, his administration also appeared ready to negotiate with the Russians at all levels. John Kerry's extensive engagement with Sergey Lavrov helped warring actors in both Ukraine and Syria to meet and bargain. Russia was not the only competitor the administration worked with. The case of Iran was probably the toughest of all. The administration faced censure from Republicans at home, and from Saudi Arabia and Israel in the Middle East for engagement with 'one of the evils. ${ }^{78}$ The Obama administration, however, moved forth with the negotiations process. It strove to increase the 'cost of cheat' for Iran because Tehran had to 'cheat' all great powers to continue with its nuclear (weapons) programme.

Engagement was not limited to Iran. In fact, the agreement with Tehran was not only about dealing with the regimes working against the US' interest. It also showed the US' willingness to work with other great powers - friends and foes - to solve problems with global implications. Obama held a similar view amid the campaign against the IS in Syria and

\footnotetext{
${ }^{75}$ The UNSC five permanent members (the P5): China, France, Russia, the United Kingdom, and the US; plus Germany.

${ }^{76}$ Rothkopf, "Obama's 'Don't Do Stupid Shit' Foreign Policy."

${ }^{77}$ Barack Obama, "Remarks by the President in State of the Union Address" (speech, Washington, D.C., January 20, 2015), White House, https://obamawhitehouse.archives.gov/the-press-office/2015/01/20/remarks-presidentstate-union-address-january-20-2015.

${ }^{78}$ Under the Bush administration, Iran was part of the 'axis of evil.'
} 
Iraq. Although the US led almost all the missions and outnumbered other states, multilateralism, justified use of force, and legitimacy were the hallmarks of the campaign. The sense of working with allies, against a threat to global peace and stability, was explicit. It had to simultaneously encourage, and limit the participating allies. The President, unequivocally, justified his approach against the IS and stressed the importance of the US-led coalition to destroy the terrorist group. ${ }^{79}$

\section{Conclusion}

John Quincy Adams (the sixth US President) once famously said that the US would not go abroad in search of monsters to destroy. ${ }^{80}$ The world has changed, however. During the Twentieth Century, the US leadership did go abroad to destroy the monsters. It took part in World War I. After the war, its leadership strove to shape the world order along liberal lines. Yet, it failed. This failure, however, influenced the leadership's post-World War II policy. FDR addressed the flaws of President Wilson's failed attempts; and his successors demonstrated the will and capacity to shape the post-WWII world. Nonetheless, not all of them pursued globally acceptable policies. The acceptance factor, in effect, lost its importance at the end of the Cold War.

An important reason for this shift in mood was the absence of a competitor, which contributed to the failure of the US' Middle East policy in the early Twenty-first Century. The Bush doctrine clearly left little space, if any, for the US' soft power to shape events. Instead, the arrogance of military power, in combination with unilateralism and disdain for neoliberal institutions, proved sufficiently detrimental to annoy allies and partners. Multiple polls and surveys showed the decline in acceptance of the US' role in the world, especially in the Muslim world. ${ }^{81}$

\footnotetext{
${ }^{79}$ Obama, "Remarks by the President in State of the Union Address."

${ }^{80}$ For details and background, see, Patrick J. Garrity, She Goes not Abroad, in Search of Monsters to Destroy: The Dispute between John Quincy Adams and Henry Clay over the South American Revolutions (Charlottesville: University of Virginia, 2009), http://www.classicsofstrategy.com/She\%20Goes\%20Not\%20Abroad.pdf.

${ }^{81}$ Gallup International Association, "Iraq Poll 2003," press release, accessed July 19, 2018,http://www.openheidoverirak.nl/dossierspdf/GIA\%20press\%20release\%20Iraq\%2 0Survey\%202003.pdf. A Gallup survey in 2003, involving 41 nations, showed
} 
An Indispensable Partner? Bush, Obama, and the US' Soft Power

Close allies, such as France and Germany, also voiced their concerns and reservations about the US' external policy. Bush's moralistic idealism had probably underplayed a challenge to his successor in the White House.

Obama's life experience, sensitivity to other cultures, ideological leanings, and pragmatism helped him understand the crisis the US faced in the aftermath of the Iraq War - a war which is still ongoing. Thus, after coming to power, Obama found it imperative to revitalise the US' moral credibility and underline soft power. He focused on asserting the US' influence in multilateral institutions and working with allies across Asia and Europe. He was ambitious to write the trade rules for the Twenty-first Century. For this purpose, he eagerly pursued the Trans-Pacific Partnership (TPP - built on Bush's initiative), and encouraged others, including China to play by the rules. He understood the importance of economic strength for a leading role in global strategic affairs.

Nonetheless, it would be a mistake to consider Obama a soft power President, and Bush a hard power President. Such a simplistic categorisation can be problematic and flawed. Both used the US' power dynamics but in different ways. Obama gave priority to diplomatic solutions and avoided initiating a new war. He was moderate and cautious in using the US' military power. His doctrine had inconsistencies, but his commitment to the notion that the US must act humbly showed that he intended to keep soft power at the core of his administration. While his actions might appear, to his domestic audience as US' declining power, they improved the country's international image. Several countries showed a higher level of confidence in his leadership.

Obama's decision to withdraw forces from Iraq, continuing Bush's plan, and Afghanistan (leaving a few thousand to assist the Afghan government) helped negate the speculations that the US intended to occupy both countries for a longer period - to contain Iran and China, respectively. He managed to assert support for Japan and other allies in

opposition to the US war in Iraq. Approximately half of the world's population did not favour military action against Iraq under any circumstances. PRC, America's Image Further Erodes, Europeans Want Weaker Ties: But Post-War Iraq Will Be Better Off, Most Say, Pew Global Attitudes Project, report (Washington, D.C.: Pew Research Centre, 2003), http://assets.pewresearch.org/wp-content/uploads/sites/2/pdf/175.pdf. A March 2003 Pew poll showed rise in anti-American views, in countries as diverse as Turkey, France, Germany, and Russia. 
the Asia-Pacific in the wake of China's assertiveness in the South China Sea and East China Sea. His administration observed the situation in the region closely and called for reaching a multilateral solution. Interestingly, these calls, in congruence with the United Nations Convention on the Law of the Sea (UNCLOS), and establishing multilateral forums to define modus operandi in the Seas came from a state that had historically preferred bilateral arrangements in the Asia-Pacific.

The Obama administration also showed willingness to limit the use of US' veto power in the UN in order to work with other UNSC members. Russia and China's objection to the creation of a no-fly zone in Syria impeded progress in resolving the conflict. At the same time, however, both sides worked with the US in negotiating with Iran. The administration worked with China in restraining North Korea through the UN sanctions. It kept pushing China to pressure its ally, and accepted South Korea's lead in diplomatic initiatives. Yet, it avoided unilateralism. The US' strategic patience, whether it worked or not depending on different perspectives, reflected restraint, and saved the country from the hubris of power. The administration also focused on engagement with Vietnam and Myanmar: US-Vietnam relations became normal state-tostate relations after the end of the arms embargo in $2016 .{ }^{82}$

US-Myanmar relations also grew during the second term of the Obama administration. Myanmar became a democracy and looked favourably towards the US. In the Americas, the thawing of relations with Cuba was a noteworthy positive step. Obama preferred engagement to rollback attempts and engaged Havana which had different domestic and external policies. He understood that Cuba posed no existential threat to the US' national security. He, thus, changed the decades-long obsolete policy that did not work after the end of the Cold War, and became the first US President to visit Cuba in five decades. ${ }^{83}$

Obama's stance on Israeli settlements in the once-Palestinian territories was also welcomed, especially across the Muslim world. Although criticised by some conservatives in the US for abandoning Israel

\footnotetext{
82 "US Completely Lifts Ban on Weapons Sale to Vietnam, Barack Obama Says," $A B C$ News, May 23, 2016, http://www.abc.net.au/news/2016-05-23/us-completely-lifts-banon-weapons-sale-to-vietnam,obama-says/7438794.

${ }^{83}$ Obama, "Remarks by the President in State of the Union Address."
} 
An Indispensable Partner? Bush, Obama, and the US' Soft Power

in the UN, his stance on settlements was just, and highlighted the negative impact it had had on the US' position in and outside the UN. It also showed that the US needed other powers' cooperation for global security and stability. After all, Obama intended to make the US an indispensable partner, rather than a patron - a partner who could keep playing a leading role in shaping the world. 